Hermanns, Pia, Shepherd, Scott, Mansor, Mohamed, Schulga, John, Jones, Jez, Donaldson, Malcolm, and Pohlenz, Joachim (2014) A new mutation in the promoter region of the PAX8 gene causes true congenital hypothyroidism with thyroid hypoplasia in a girl with Down's syndrome. Thyroid, 24 (6). pp. 939-944. ISSN 1050-7256

Copyright (c) 2014 Mary Ann Liebert, Inc.

A copy can be downloaded for personal non-commercial research or study, without prior permission or charge

Content must not be changed in any way or reproduced in any format or medium without the formal permission of the copyright holder(s)

When referring to this work, full bibliographic details must be given

http://eprints.gla.ac.uk/94956/

Deposited on: 10 July 2014

Enlighten - Research publications by members of the University of Glasgow http://eprints.gla.ac.uk 


\title{
A New Mutation in the Promoter Region of the PAX8 Gene Causes True Congenital Hypothyroidism with Thyroid Hypoplasia in a Girl with Down's Syndrome
}

\author{
Pia Hermanns, ${ }^{1}$ Scott Shepherd, ${ }^{2}$ Mohamed Mansor, ${ }^{3}$ John Schulga, ${ }^{3}$ \\ Jez Jones, ${ }^{2}$ Malcolm Donaldson, ${ }^{2}$ and Joachim Pohlenz ${ }^{1}$
}

Background: Thyroid dysfunction is common in newborn infants with Down's syndrome (DS), but defects causing classic thyroid dysgenesis (TD) with permanent congenital hypothyroidism $(\mathrm{CH})$ have not been described.

Objective: We studied a girl with DS and $\mathrm{CH}$ who had a mutation in the promoter sequence of the PAX8 gene. Results: A female infant was found to have trisomy 21 and $\mathrm{CH}$, with a venous thyrotropin (TSH) of $>150 \mathrm{mU} / \mathrm{L}$ and a free thyroxine (fT4) of $15.1 \mathrm{pmol} / \mathrm{L}$ (day 12). Thyroid peroxidase antibodies and thyroglobulin antibodies were elevated. Scintigraphy showed normal uptake, but ultrasound identified a small gland with heterogenous echotexture and cystic changes. Sequence analysis of the PAX8 gene revealed a new heterozygous maternally inherited mutation $(-3 \mathrm{C}>\mathrm{T})$ close to the transcription initiation site. Electromobility shift assay studies of the wild type and the mutant $P A X 8$ sequence incubated with nuclear extracts from PCCL3 cells exhibited that the sequence at position -3 is not involved in specific protein binding. However, the mutant PAX8 promoter showed a significantly reduced transcriptional activation of a luciferase reporter gene in vitro tested in HEK, PCCL3, as well as in HeLa cells, indicating that this mutation is very likely to lead to reduced PAX8 expression.

Conclusions: The persistent $\mathrm{CH}$ in this patient with DS is likely to be attributable to the diminished PAX8 expression due to a new heterozygous mutation in the $P A X 8$ promoter sequence. Our case shows that true $\mathrm{CH}$ may occur in DS, as in the general population. Furthermore, it is possible that the trisomy 21 itself may have resulted in a more severe phenotypic expression of the PAX8 mutation in the child than the mother.

\section{Introduction}

C Ongenital hyPOTHYROIDISM (CH) is the most common inborn endocrine disorder and is usually caused by either thyroid dysgenesis (TD) or thyroid dyshormonogenesis. In the majority of cases (80-85\%), $\mathrm{CH}$ is due to $\mathrm{TD}$, which usually takes the form of an absent or ectopic gland, representing a defect in thyroid migration (1). More rarely, TD results in a hypoplastic thyroid gland in situ, a phenotype accounting for about $10 \%$ of all cases of $\mathrm{CH}$ (2). The molecular mechanisms leading to TD are mostly unknown. So far, only a few single gene mutations have been identified when the known candidate genes (thyroid transcription factors 1 and 2 (TTF1 and TTF2), the thyrotropin-receptor (TSHR), the NK2 transcription factor related locus 5 (NKX2.5), and the paired box gene 8 (PAX8)) of individuals with TD were investigated (3). One of those candidate genes for TD-the
PAX8 gene-is of particular interest, since mutations in this gene can be associated with a highly variable phenotype presenting with TD or even a normal thyroid gland within the same family (4), raising the possibility of incomplete penetrance or the presence of genetic or nongenetic modifiers (5). Recently, we identified a mutation in the promoter sequence of the PAX8 gene to be causative for TD in a girl who also had a $N K X 2.5$ gene mutation (6). We have therefore begun to analyze the promoter sequence of the $P A X 8$ gene in other patients with TD who did not harbor a mutation in the coding regions of the known candidate genes for TD.

Down's syndrome (DS) is the most common chromosomal disorder with an adjusted prevalence in the United Kingdom of 1.08 per 1000 live births (7). Thyroid dysfunction is common, particularly acquired autoimmune thyroiditis (8). In newborn infants, thyrotropin (TSH) elevation is often seen and is typically transient in nature (9), possibly reflecting

\footnotetext{
${ }^{1}$ Department of Pediatrics, Johannes Gutenberg University Medical School, Mainz, Germany.

${ }^{2}$ Section of Child Health, School of Medicine, Royal Hospital for Sick Children, Glasgow, Scotland.

${ }^{3}$ Department of Paediatrics, Forth Valley Royal Hospital, Larbert, Scotland.
} 
altered regulation of the thyroid axis (10). However, classic $\mathrm{CH}$ with dysgenesis is not an established feature in DS.

We describe a new mutation close to the transcription initiation site of the $P A X 8$ gene in a girl with DS and thyroid hypoplasia. In vitro studies show that this mutation causes a reduction in the $P A X 8$ gene expression level, and is therefore very likely to be causative.

\section{Case Report}

Our patient, a female, was born after 40 weeks of gestation by spontaneous vaginal delivery as a breech presentation to a 24-year-old mother with no history of thyroid disease following a normal pregnancy. Dysmorphic features consistent with DS were noted shortly after birth, and karyotype examination confirmed trisomy 21. A cardiac ultrasound showed a large perimembranous ventricular septal defect (VSD), a secundum atrial septal defect (ASD), and a patent ductus arteriosus (PDA). Elective repair was planned, but at 35 days, the baby was admitted with failure to thrive and cardiac failure. She was commenced on nasogastric feeding and regular diuretics, and subsequently underwent Dacron patch closure of her VSD, a direct suture closure of her ASD, and a ligation of her PDA at the age of 69 days. She was readmitted on day 106 with respiratory distress and stridor, and was found to have supraglottic edema consistent with reflux laryngitis. A barium swallow confirmed significant gastroesophageal reflux, and she underwent fundoplication and gastrostomy insertion at day 133 . Her gastrostomy has remained in situ since discharge, and she required readmission at the age of 2.25 years for open jejunostomy and reinsertion of the gastrostomy.

\section{Thyroid features}

Newborn blood spot screening on day 5 demonstrated hyperthyrotropinemia at $43.8 \mathrm{mU} / \mathrm{L}$ in whole blood (normal $<8 \mathrm{mU} / \mathrm{L}$ ). At the time of referral (day 12), she was noted to be constipated and suffering from prolonged neonatal jaundice, and a venous blood sample showed a serum TSH of $>150 \mathrm{mU} /$ $\mathrm{L}$ (normal 0.72-13.1 mU/L) and a normal free thyroxine (fT4) of $15.1 \mathrm{pmol} / \mathrm{L}$ (normal $8-25 \mathrm{pmol} / \mathrm{L}$ ) indicating compensated primary $\mathrm{CH}$. Thyroid peroxidase antibodies (TPOAb) were elevated at $409 \mathrm{IU} / \mathrm{mL}$ (normal $<50 \mathrm{IU} / \mathrm{mL}$ ) consistent with transplacental transfer of maternal thyroid antibodies. Unfortunately, however, there is no record of maternal thyroid function tests from this time. The infant was commenced on levothyroxine at 25 and $50 \mu \mathrm{g}$ on alternate days. Thyroid function tests were repeated on day 28 and demonstrated a good response to levothyroxine with a serum TSH of $11.03 \mathrm{mU} / \mathrm{L}$ (normal $0.72-13.1 \mathrm{mU} / \mathrm{L}$ ), a fT4 of $31.9 \mathrm{pmol} / \mathrm{L}$ (normal 8 $25 \mathrm{pmol} / \mathrm{L}$ ), and a free triiodothyronine (fT3) of $2.2 \mathrm{nmol} / \mathrm{L}$ (normal $0.9-2.8 \mathrm{nmol} / \mathrm{L}$ ). Her thyroglobulin was $103 \mathrm{ng} / \mathrm{mL}$ (normal $<55 \mathrm{ng} / \mathrm{mL}$ ), and thyroglobulin antibodies were $<20 \mathrm{IU} / \mathrm{L}$ (normal < $40 \mathrm{IU} / \mathrm{L}$ ). In light of these results, her levothyroxine dose was adjusted to $25 \mu \mathrm{g}$ daily.

Combined ultrasound and radioisotope imaging of the thyroid gland was performed on day 14. An ultrasound showed a small gland with a right lobe volume of $0.44 \mathrm{~mL}$, a left lobe volume of $0.31 \mathrm{~mL}$, and a combined volume of $0.76 \mathrm{~mL}$ (reference range $1.0-3.3 \mathrm{~mL}$ ) (6). The gland was very heterogeneous in echotexture with many small and two large cystic areas. The isthmus appeared bulky, measuring $0.26 \mathrm{~mL}$. A radioisotope thyroid scan after intravenous injection of
$10 \mathrm{MBq}$ of pertechnetate showed a normal uptake in an apparently normal bilobed thyroid gland in a normal position.

At 1.35 years, her TSH was very elevated at $>150 \mathrm{mU} / \mathrm{L}$ (normal $0.46-8 \mathrm{mU} / \mathrm{L}$ ) with a fT4 of $9.3 \mathrm{pmol} / \mathrm{L}$ (normal 9$23 \mathrm{pmol} / \mathrm{L}$ ) despite treatment with $43.75 \mu \mathrm{g}$ of levothyroxine daily, suggestive of compliance difficulties. The levothyroxine dose was increased to $50 \mu \mathrm{g}$ daily, and her thyroid function remained normal thereafter.

At 3.8 years, the dose of levothyroxine was reduced to $25 \mu \mathrm{g}$ daily to establish whether the child's $\mathrm{CH}$ was transient or permanent in nature. Six weeks later, her TSH had risen to $53.61 \mathrm{mU} / \mathrm{L}$ (reference range $0.35-5.5 \mathrm{mU} / \mathrm{L}$ ) with a fT4 of $12.1 \mathrm{pmol} / \mathrm{L}$ (reference range $9-24 \mathrm{pmol} / \mathrm{L}$ ) confirming the persistence of primary hypothyroidism, and the levothyroxine dose was increased back to $50 \mu \mathrm{g}$ daily.

At the same time, the mother was found to have a TSH of $16.13 \mathrm{mU} / \mathrm{L}$, a fT4 of $12.6 \mathrm{pmol} / \mathrm{L}$, and TPOAb >1000 IU/ $\mathrm{mL}$, and treatment with levothyroxine was initiated.

After obtaining informed written consent, molecular genetic studies were conducted.

\section{Material and Methods}

\section{Subjects, DNA amplification, and DNA sequencing}

We obtained written informed consent from all available family members to participate in the clinical and genetic studies. Genomic DNA from blood samples was isolated utilizing the Puregene ${ }^{\circledR}$ Blood Core Kit B (Qiagen, Hilden, Germany). The coding sequences of the candidate genes for $\mathrm{TD}$, as well as the promoter sequence of the $P A X 8$ gene, were amplified by polymerase chain reaction (PCR; conditions and primer sequences for mutational screening of TSHR, PAX8, $T T F 1, T T F 2$, and $N K X 2.5$ can be supplied upon request), purified with the HiYield ${ }^{\circledR}$ PCR Clean-up/Gel Extraction Kit (Süd-Laborbedarf GmbH, Gauting, Germany), and then sequenced with BigDye terminator v.3.1 purified by ethanol precipitation and analyzed using an automated sequencing system (3130 Avant Genetic Analyzer, Applied Biosystems, Weiterstadt, Germany).

\section{Constructs and mutagenesis}

To study the consequence of the $P A X 8$ promoter mutation, a $1130 \mathrm{bp}$ fragment upstream of the ATG of the PAX8 gene was amplified and cloned upstream of the luciferase gene of the pGL3 basic vector (Promega, Madison, WI). This promoter construct (PAX8proWT) was a gift from Dr. Peter Kopp (Northwestern University, Chicago, IL). To construct the $P A X 8$ promoter mutation (PAX8proMUT), we used the Quick Change Mutagenesis XL kit (Agilent Technologies, La Jolla, CA) and the primers PAX8_-3-F: 5'-GGT GAT GCC GGG TGA ATG GGA ACA AAC-3' and PAX8_-3_R: 5'-GTT TGT TCC CAT TCA CCC GGC ATC ACC $-3^{\prime}$ respectively. All constructs were verified by sequencing.

\section{Cell culture and transfection}

HeLa and HEK cells were grown in PAN 401 medium supplemented with $10 \%$ fetal bovine serum (FBS; PAN Biotech $\mathrm{GmbH}$, Aidenbach, Germany) and $1 \%$ penicillinstreptomycin (PAN Biotech $\mathrm{GmbH}$ ) at $37^{\circ} \mathrm{C}$ in a humidified chamber with $5 \% \mathrm{CO}_{2}$. PCCL3 cells were a gift from 
Dr. Annette Altmann (Clinical Cooperation Unit, Nuclear Medicine, Heidelberg, Germany), and were grown in Ham's F12 K medium supplemented with $10 \% \mathrm{FBS}, 1 \%$ penicillinstreptomycin (PAN Biotech $\mathrm{GmbH}), 10 \mathrm{ng} / \mathrm{mL}$ somatostatin, $10 \mathrm{ng} / \mathrm{mL}$ Glys-His-Lys, $5 \mu \mathrm{g} / \mathrm{mL}$ transferin, $10 \mathrm{nM}$ hydrocortisone, $10 \mu \mathrm{g} / \mathrm{mL}$ insulin, and $10 \mathrm{mU} / \mathrm{mL}$ TSH (SigmaAldrich, St. Louis, MO) at $37^{\circ} \mathrm{C}$ in a humidified chamber with $5 \% \mathrm{CO}_{2}$. Twelve hours before transfection, cells were trypsinized and plated in wells on a 24-well plate. When the cells reached a confluence of $70 \%$, transfection with FuGene HD (Roche, Mannheim, Germany) was carried out according to the manufacturer's instructions. The ratio of the transfection reagent to DNA was 2:3. Forty-eight hours after transfection, the cells were washed three times with ice cold phosphatebuffered saline (PBS; Invitrogen, Carlsbad, CA) and lysed in $150 \mu \mathrm{L}$ of $1 \times$ passive lysis solution (Promega). Ten $\mu \mathrm{L}$ of the protein extract was used for the dual luciferase assay (Promega). The measurement of the firefly and the Renilla luciferase activity was performed according to the manufacturer's recommendations.

\section{Electromobility shift assay (EMSA)}

The proteins from nuclear extracts from HeLa, PCCL3, and HEK cells were isolated as described previously (11). The wild type as well as the mutant $P A X 8$ promoter oligo sequences were 5'-end-labeled with IRD700 (Metabion, Martinsried, Germany). The $10 \mu \mathrm{L}$ binding reaction contained $1 \mu \mathrm{g}$ of protein, $10-50 \mathrm{nM}$ oligo, $150 \mathrm{ng}$ poly (dI-dC), $500 \mathrm{ng}$ salmon sperm DNA, $5 \mathrm{mM}$ DTT, $0.5 \%$ Tween20, $10 \mathrm{mM}$ Tris, and $50 \mathrm{mM} \mathrm{NaCl} \mathrm{pH} \mathrm{7.5.} \mathrm{The} \mathrm{binding} \mathrm{reaction}$ was incubated for $30 \mathrm{~min}$ at room temperature. Afterwards, $1 \mu \mathrm{L}$ gel-loading buffer (containing $650 \mathrm{mg} / \mathrm{mL}$ sucrose, $0.3 \%$ OrangeG, $10 \mu \mathrm{M}$ Tris $\mathrm{pH} 7.5$, and $10 \mu \mathrm{M}$ EDTA $\mathrm{pH}$ 8.0) was added, and the samples were loaded on a $4 \%$ native polyacrylamide (PAA) gel. The PAA gel was supplemented with $50 \mathrm{mM}$ Tris $\mathrm{pH} 7.5,200 \mathrm{mM}$ glycine, $2 \mathrm{mM}$ EDTA. Towbin buffer (12) supplemented with $10 \mathrm{mM}$ EDTA served as a running buffer. Thereafter, the PAA gels were scanned and visualized using the Odyssey Model 9120 and the Odyssey v2.1 software (Li-Cor Biosciences, Bad Homburg, Germany).

To test the protein binding capacity of the wild type and the mutant promoter, the primers used for mutagenesis of $P A X 8$ proWT and $P A X 8$ proMUT were labelled with an infrared dye (IRD700) and incubated with proteins of a nuclear extract isolated from HeLa cells, PCCL3 cells, or HEK cells.

\section{Results}

Sequence analysis of the proposita's genomic DNA revealed a heterozygous mutation in the promoter sequence of the $P A X 8$ gene at position -3 upstream of exon $1(\mathrm{G}>\mathrm{A})$. This is $562 \mathrm{bp}$ upstream of the translation start site in exon 2 . This mutation is located in a highly conserved area of the PAX8 gene promoter (data not shown). It was not found in 100 normal alleles, making a common polymorphism unlikely. The mutation was also found in a heterozygous state in the mother of the proposita.

To study the consequence of the nucleotide substitution in the $P A X 8$ promoter region, both reporter constructs (PAX8proWT and $P A X 8$ proMUT) driving a luciferase reporter gene were transiently transfected into HeLa, PCCL3, and HEK

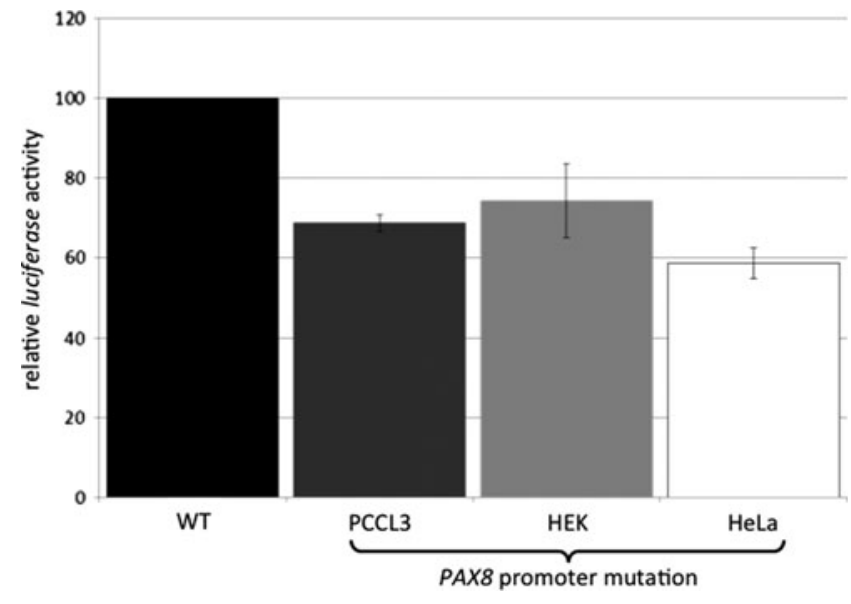

FIG. 1. In vitro effects of the $P A X 8$ promoter mutation. Both $P A X 8$ gene promoter constructs (PAX8proWT and $P A X 8$ proMUT) were transiently transfected into PCCL3, HEK, or HeLA cells. Using $1 \mu \mathrm{g}$ of plasmid DNA of each promoter construct, a significant decrease of the luciferase expression was observed with the PAX8proMut compared to the $P A X 8$ proWT (dark black bar) in all three cell lines.

cells respectively. Using $1 \mu \mathrm{g}$ of plasmid DNA of each promoter construct, a significant decrease of the luciferase expression was observed with the $P A X 8$ proMut construct compared to the $P A X 8$ proWT in all three cell lines (Fig. 1). We then investigated the ability of nuclear extracts from HeLa, HEK, and PCCL3 cells to bind to the investigated $P A X 8$ promoter sequence. Neither the investigated wild type promoter sequence nor the mutant $P A X 8$ promoter sequence showed a specific shift (Fig. 2), indicating that this sequence is not important for specific protein binding.

\section{Discussion}

We report the case of a girl with DS who had $\mathrm{CH}$ attributable to thyroid hypoplasia associated with a heterozygous

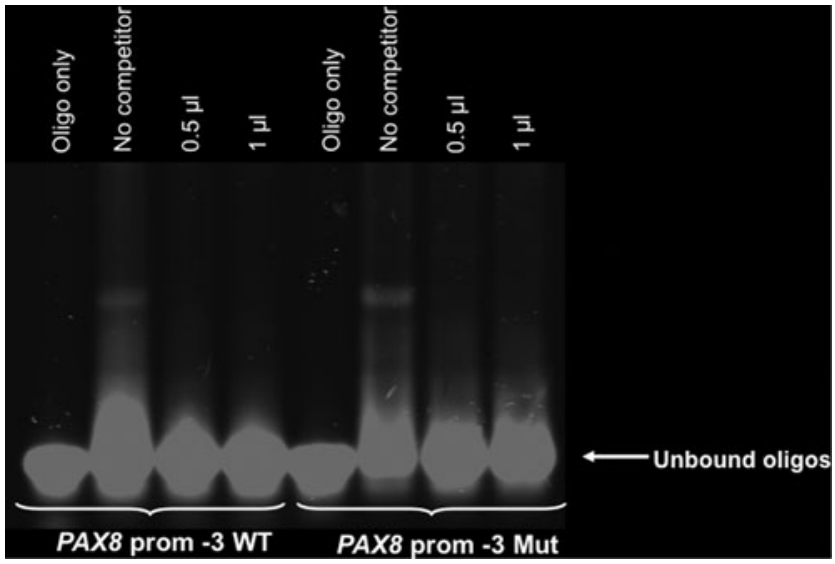

FIG. 2. Electromobility shift assay (EMSA) with nuclear extracts from PCCL3 and PAX8proWT and PAX8proMUT. Nuclear extracts isolated from PCCL3 cells were incubated with double stranded (ds) oligonucleotides containing either the wild type or the mutant $P A X 8$ promoter sequence. No specific protein binding to either double stranded oligo was observed. 
mutation close to the transcription initiation site sequence of the $P A X 8$ promoter, which was inherited from the mother. In our case, there was evidence of maternal Hashimoto's disease in that elevated TPO antibodies were detected in the infant during the postnatal period, while the mother showed very high TPO antibodies together with compensated primary hypothyroidism (normal fT4 but elevated TSH) when the girl was reevaluated at 3.5 years of age.

It is known that infants with DS commonly show TSH elevations $(9,10)$, which raises the possibility that the thyroid dysfunction in our case could simply represent a nonspecific effect of DS. Alternatively, it could be argued that the $\mathrm{CH}$ in our patient resulted from transplacental transfer of maternal thyroid antibodies.

Concerning the first point, it is true that TSH elevations occur more commonly in DS, as for example when detected by newborn screening, compared with the general population $(13,14)$. However, there is no evidence that the incidence of the classic cause of true permanent $\mathrm{CH}-\mathrm{TD}$ - is more common in DS. Indeed, studies to date have shown the thyroid gland is neither ectopic nor absent in DS. Fort et al. described the clinical characteristics of 11 DS newborns detected by neonatal screening, none of whom had athyreosis or thyroid ectopia (13). Moreover, a recent study of 13 fetuses with DS by Luton et al. found no abnormality, including goiter, on ultrasonography, although heterogeneity of the glands and reduced follicular size on histology was found (15). However, it should be noted that detailed, high-resolution imaging of the thyroid in DS has not been carried out in a prospective fashion, and hence mild alterations in size may have previously gone undetected.

By contrast, it is well established that TSH levels tend to be elevated in newborns with DS $(9,10)$. Van Trotsenburg et al. found a shift toward relatively higher TSH and lower fT4 levels in 97 placebo-treated infants with DS, while 99 DS infants treated with levothyroxine needed relatively high fT4 concentrations to normalize TSH (16). This group concluded that a type of mild, persistent $\mathrm{CH}$ occurs in DS, possibly related to the genomic dosage imbalance of dosage-sensitive genes interfering with thyroid hormone production. This conjecture is supported by a recent study by Myerovitch et al., who found a significant shift of the TSH distribution curve to higher values compared with the general population (17), and also of Luton et al., who found TSH elevations with low fT4 levels yet no goiter in 6 of the 13 fetuses with DS studied, indicating a degree of TSH resistance (15). Thus, according to van Trotsenburg et al., many infants with DS who are detected with raised TSH in the newborn period may simply represent those at the extreme end of abnormal thyroid function parameters due to what can be regarded as a DSspecific type of $\mathrm{CH}$ (16).

It is clear that our case is different from the model of TSH resistance described above. The finding of actual thyroid gland hypoplasia, with dysplastic features comprising cystic changes on ultrasound, is not consistent with the thyroid dysfunction associated with DS in the newborn period reported previously. Similarly, transplacental transfer of maternal antibodies, while known to cause transient $\mathrm{CH}$ (18), would not be expected to cause true, permanent $\mathrm{CH}$ as in our case, in whom a significant TSH elevation $(>50 \mathrm{mU} / \mathrm{L})$ occurred when the levothyroxine dose was reduced from 50 to $25 \mu \mathrm{g}$ at three years of age.
It is our belief that the $\mathrm{CH}$ in our patient with DS is due to the finding of a mutation in the PAX 8 promoter. So far, two monoallelic mutations in the $P A X 8$ promoter region have been described in individuals with TD $(2,6)$, but in vitro functional studies were only performed in one case (6). We therefore decided to investigate whether the mutation at position -3 found in our patient is pathogenic by performing in vitro studies. As expected, the mutant $P A X 8$ gene promoter showed a significantly $(25 \%)$ reduced ability to activate a reporter gene compared to the wild type (Fig. 1). This result is likely to be due to the fact that the mutant has impact on the initiation of the transcriptional process (19). This is because this part of the promoter sequence is recognized by the transcription initiation complex and is thus important for proper binding of the DNA-dependent RNA polymerase II (20). We therefore postulate that $-3 \mathrm{G}>\mathrm{A}$ is very likely to be pathogenic, since this mutation falls directly into the conserved sequence of the transcription initiator element (21).

The fact that both the normal $P A X 8$ promoter and the mutant sequence did not bind specific nuclear proteins present in PCCL3, HeLa, or HEK cells in our EMSA experiments (Fig. 2) is not contradictory to our functional studies of the promoter. This is because the double stranded oligonucleotide investigated covers only a small part of the promoter region. It is possible, therefore, that if a larger piece of the transcriptional machinery had been investigated, the altered sequence might have had an impact on the binding of the transcriptional machinery in contrast to the normal $P A X 8$ promoter. We do not believe that the reduction in transcriptional activity, which we have found, is caused by a thyroid specific factor, since we have observed this not only in thyroid cells (PCCL3), but also in HEK and HeLa cells. Work by Nitsch et al. supports our hypothesis, since this group identified a thyroid-specific transcriptional enhancer element $84 \mathrm{~kb}$ upstream of the $P A X 8$ transcription start site (22). Taken together, our in vitro findings suggest that the altered promoter leads to reduced $P A X 8$ gene expression, which is likely to be involved in the pathogenesis of TD in our index patient.

The question arises as to why true permanent $\mathrm{CH}$ has occurred in our index case with DS whereas the mother was initially euthyroid, although she developed hypothyroidism due to her Hashimoto's disease. It is known that PAX8 mutations produce a highly variable phenotype $(3,4,6,23-$ $25)$. It is therefore not surprising that the mother, who is also a heterozygous carrier of the monoallelic PAX8 gene mutation, was initially phenotypically normal. Our case is similar to that of Congdon et al., who reported a girl with $\mathrm{CH}$ in association with a eutopic hypoplastic thyroid gland, who had a heterozygous transversion 119A- $>$ C in exon 3 of $P A X 8$ replacing a conserved glutamine by proline in the paired box domain (Q40P) (26). The child's mother was also heterozygous for this mutation but had a thyroid gland of normal size and mild, adult-onset autoimmune hypothyroidism. It is of interest that the mothers in both our study and the report by Congdon et al. had autoimmune hypothyroidism, raising the possibility that a $P A X 8$ alteration might render the individual more prone to autoimmune thyroid disease.

It remains unclear in what way this phenotypic variability is due to variable penetrance or expressivity of the 
mutant gene, or whether the genetic background plays a role in this context. Moreover, haploinsufficiency, monoallelic expression, or imprinting could impact on the phenotype (5).

It is possible that the $\mathrm{CH}$ related to a $P A X 8$ mutation that has been inherited from the mother was completely independent of the child's trisomy 21 in our case. If this is so, our case serves to illustrate that $\mathrm{CH}$, which has an incidence of about 1 in 3000 births, may occur in DS just as it does in the general population, and that infants with DS and significant TSH elevations are entitled to the same investigation, including thyroid imaging, as other infants who are detected on newborn screening. However, it is also possible that the genomic imbalance related to trisomy 21 in our patient may have resulted in a more severe expression of the $P A X 8$ gene mutation, which she had inherited from her mother.

\section{Acknowledgments}

We thank Michaela Bartusel and Farah Izadpanah for excellent technical assistance. P.H. was supported from the MAIFOR program, Germany. Furthermore, we thank all family members for their participation in this study, and Dr. Peter Kopp (Northwestern University, Chicago, IL) for providing the $P A X 8$ wild type promoter construct.

\section{Author Disclosure Statement}

The authors have nothing to disclose.

\section{References}

1. De Felice M, Di Lauro R 2004 Thyroid development and its disorders: genetics and molecular mechanisms. Endocr Rev 25:722-746.

2. Ramos HE, Nesi-Franca S, Boldarine VT, Pereira RM, Chiamolera MI, Camacho CP, Graf H, de Lacerda L, Carvalho GA, Maciel RM 2009 Clinical and molecular analysis of thyroid hypoplasia: a population-based approach in southern Brazil. Thyroid 19:61-68.

3. Pohlenz J, van Vliet G 2010 Developmental abnormalities of the thyroid. In: Weiss RE, Refetoff $S$ (eds) Genetic Diagnosis of Endocrine Disease. Vol. 1. Elsevier, New York, pp. 97-104.

4. de Sanctis L, Corrias A, Romagnolo D, Di Palma T, Biava A, Borgarello G, Gianino P, Silvestro L, Zannini M, Dianzani I 2004 Familial PAX8 small deletion (c.989_992de1ACCC) associated with extreme phenotype variability. J Clin Endocrinol Metab 89:5669-5674.

5. Vassart G, Dumont JE 2005 Thyroid dysgenesis: multigenic or epigenetic...or both? Endocrinology 146:5035-5037.

6. Hermanns P, Grasberger H, Refetoff S, Pohlenz J 2011 Mutations in the NKX2.5 gene and the PAX8 promoter in a girl with thyroid dysgenesis. J Clin Endocrinol Metab 96:E977-981.

7. Morris JK, Alberman E 2009 Trends in Down's syndrome live births and antenatal diagnoses in England and Wales from 1989 to 2008: analysis of data from the National Down Syndrome Cytogenetic Register. BMJ 339:b3794.

8. Claret C, Goday A, Benaiges D, Chillaron JJ, Flores JA, Hernandez E, Corretger JM, Cano JF 2013 Subclinical hypothyroidism in the first years of life in patients with Down syndrome. Pediatr Res 73:674-678.

9. Pozzan GB, Rigon F, Girelli ME, Rubello D, Busnardo B, Baccichetti C 1990 Thyroid function in patients with Down syndrome: preliminary results from non-institutionalized patients in the Veneto region. Am J Med Genet Suppl 7:57-58.

10. van Trotsenburg AS, Vulsma T, van Santen HM, Cheung W, de Vijlder JJ 2003 Lower neonatal screening thyroxine concentrations in down syndrome newborns. J Clin Endocrinol Metab 88:1512-1515.

11. Schreiber E, Matthias P, Muller MM, Schaffner W 1989 Rapid detection of octamer binding proteins with "miniextracts," prepared from a small number of cells. Nucleic Acids Res 17:6419.

12. Towbin H, Staehelin T, Gordon J 1979 Electrophoretic transfer of proteins from polyacrylamide gels to nitrocellulose sheets: procedure and some applications. Proc Natl Acad Sci U S A 76:4350-4354.

13. Fort P, Lifshitz F, Bellisario R, Davis J, Lanes R, Pugliese M, Richman R, Post EM, David R 1984 Abnormalities of thyroid function in infants with Down syndrome. J Pediatr 104:545-549.

14. Oakley GA, Muir T, Ray M, Kennedy R, Girdwood RWA, Donaldson MDC 1998 Increased incidence of congenital malformation in infants with TSH elevation detected on newborn screening. J Pediatr 132:726-730.

15. Luton D, Azria E, Polak M, Carre A, Vuillard E, Delezoide AL, Guibourdenche J 2012 Thyroid function in fetuses with down syndrome. Horm Res Paediatr 78:88-93.

16. van Trotsenburg AS, Kempers MJ, Endert E, Tijssen JG, de Vijlder JJ, Vulsma T 2006 Trisomy 21 causes persistent congenital hypothyroidism presumably of thyroidal origin. Thyroid 16:671-680.

17. Meyerovitch J, Antebi F, Greenberg-Dotan S, Bar-Tal O, Hochberg Z 2012 Hyperthyrotropinaemia in untreated subjects with Down's syndrome aged 6 months to 64 years: a comparative analysis. Arch Dis Child 97:595-598.

18. Mengreli C, Maniati-Christidi M, Kanaka-Gantenbein C, Girginoudis P, Vagenakis AG, Dacou-Voutetakis C 2003 Transient congenital hypothyroidism due to maternal autoimmune thyroid disease. Hormones (Athens) 2:113-119.

19. Kozak M 1987 An analysis of 5'-noncoding sequences from 699 vertebrate messenger RNAs. Nucleic Acids Res 15: 8125-8148.

20. Smale ST, Kadonaga JT 2003 The RNA polymerase II core promoter. Annu Rev Biochem 72:449-479.

21. Corden J, Wasylyk B, Buchwalder A, Sassone-Corsi P, Kedinger C, Chambon P 1980 Promoter sequences of eukaryotic protein-coding genes. Science 209:1406-1414.

22. Nitsch R, Di Dato V, di Gennaro A, de Cristofaro T, Abbondante S, De Felice M, Zannini M, Di Lauro R 2010 Comparative genomics reveals a functional thyroid-specific element in the far upstream region of the PAX8 gene. BMC Genomics 11:306.

23. Narumi S, Araki S, Hori N, Muroya K, Yamamoto Y, Asakura Y, Adachi M, Hasegawa T 2012 Functional characterization of four novel PAX8 mutations causing congenital hypothyroidism: new evidence for haploinsufficiency as a disease mechanism. Eur J Endocrinol 167:625-632.

24. Carvalho A, Hermanns P, Rodrigues AL, Cabral R, Bikker H, Sousa I, Anselmo JD, Pereira-Duarte C, Mota-Vieira L, 
Pohlenz J 2013 A new Pax8 mutation causing congenital hypothyroidism in three henerations of a family is associated with abnormalities in the urogenital tract. Thyroid 23:1074-1078.

25. Macchia PE, Lapi P, Krude H, Pirro MT, Missero C, Chiovato L, Souabni A, Baserga M, Tassi V, Pinchera A, Fenzi G, Gruters A, Busslinger M, Di Lauro R 1998 PAX8 mutations associated with congenital hypothyroidism caused by thyroid dysgenesis. Nat Genet 19:83-86.

26. Congdon T, Nguyen LQ, Nogueira CR, Habiby RL, Medeiros-Neto G, Kopp P 2001 A novel mutation (Q40P) in PAX8 associated with congenital hypothyroidism and thyroid hypoplasia: evidence for phenotypic variability in mother and child. J Clin Endocrinol Metab 86:3962-3967.

Address correspondence to:

Joachim Pohlenz, MD, PhD

Department of Pediatrics

Johannes Gutenberg University Medical School

Langenbeckstrasse 1

D-55101 Mainz

Germany

E-mail: pohlenz@uni-mainz.de 